\title{
SELF-CARE NEEDS IN PATIENTS WITH PHYSICAL IMMOBILIZATION
}

\author{
Novia Shinthia Dewie, Eka Misbahatul Mar'ah Has \\ Faculty of Nursing Universitas Airlangga, Kampus C Mulyorejo Surabaya, 60115 \\ Email: eka.m.has@fkp.unair.ac.id
}

\begin{abstract}
Introduction: The quantity of unfulfilment of self-care in patients with physical immobilisation can decrease the quality indicator of nursing care. Self-care for physically immobilised patients is affected by basic condition factors. The study aimed to analyse the factors that can affect the fulfilment of self-care needs in patients with physical immobilisation. Methods: The study design was descriptive cross-sectional, with purposive sampling technique and the samples were 36 nurses and 36 physically immobilised patients. The independent variable was the fulfilment of self-care needs. Dependent variables were patient demography (age, sex), nurse (knowledge, action, motivation), and health care factors (occupation design/nursing care method). The instrument used was a questionnaire and observation form. Data were then analysed using double linear regression analysis, with significance $a \leq 0.05$. Results: From the double linear regression test result was obtained $p$-value $(\operatorname{Sig})=0.000 \mathrm{R}$ Square $=0.889$. Partially it was obtained $\mathrm{p}$-value of age $\mathrm{p}(\mathrm{sig})=0,005$, $\operatorname{sex} \mathrm{p}(\operatorname{Sig})=0.038$, knowledge $\mathrm{p}(\operatorname{Sig})=0.889$, action $\mathrm{p}(\mathrm{Sig})=0.000$, and motivation $\mathrm{p}(\mathrm{Sig})=0.003$. Conclusion: Factors of patients (age, sex $)$ and nurses (action, motivation) influence the fulfilment of self-care needs for patients with physical immobilisation. However, nurses' knowledge does not have any influence. The study result can be considered as input for nurses in developing the quality of nursing care in the fulfilment of self-care needs.
\end{abstract}

Keywords: basic conditioning factor, physical immobilized patient, self-care

\section{INTRODUCTION}

Basic human needs are the focus in nursing care. Physical needs are the greatest needs, including nutrition, rest, oxygen, elimination and sexual activity, and should be fulfilled more; therefore, the nurse must have the ability and knowledge regarding the fulfilment of basic human needs, with the ability to monitor and follow the development of the patient in carrying out the activities of daily life to meet the basic needs, especially in patients with immobilisation (Damayanti 2010). Orem (1979, cited in Galegos, 1997) states that personal care (self-care) as an activity of daily life is made to meet the physical needs. Self-care is influenced by factors of the basic conditions (basic conditioning factor). These factors are classified into 3 categories, namely individual factors (age, gender, stage of development), factors of individual situations with family and social group (orientation sociocultural and family systems, and placements factor, health status, health care system/health, lifestyle, environment, and the availability and adequacy of resources). Patients' physical immobilisation needs, especially the needs of self-care, cannot be met without the help of a nurse; the nurse must establish a therapeutic relationship with the patient in order to create a relationship of trust and caregivers for better understanding the needs of the patient (Thistle 2010).

Immobility or immobilisation is the inability to move freely due to a condition whereby the movement is interrupted or limited (Potter and Perry 2013). Immobilisation is an inability to transfer or change position or bed rest for 3 days or more, with the motion of the anatomical body disappearing due to changes in physiological functioning (Setiati et al. 2015). It prevents immobile patients with physical immobilisation from meeting their own needs independently. Nurses and family members should assist in the fulfilment of their needs, including the self-care needs (Thistle 2010).

Nurses have some role in carrying out their duties in accordance with the rights and responsibilities that exist (Asmadi 2008). One of the nurse's roles is as a care provider. The role of the nurse as care provider must be implemented comprehensively and completely, not just focusing on the actions of promotion but also on preventative measures such as the implementation of personal hygiene in self-care needs. The role of the nurse as care provider in the implementation of personal hygiene will be more dominant when involving patients with physical immobilisation. It is meaningful in professional nursing care in accordance with the rules of nursing as a profession. One of the characteristics of the profession is oriented to service using expertise for the sake of the needs of patients, including the fulfilment of basic needs (Hidayat, 2008).

Based on Gunadi (2001), at Cipto 
Mangunkusumo Orthopedic Surgery suggests that nurses have not implemented to give selfcare needs optimally. Another study states that the role of nurses in the implementation of personal hygiene according to the patients' perceptions on physical immobilisation showed that as many as 64 respondents (45.4\%) found it to be poor (Sulistyowati and Hand, 2012).

Based on the initial survey conducted by researchers during two weeks in November 2016, in the inpatient unit Graha Afiyah RSU Haji Surabaya Nuur data showed that there were as many as 21 patients with physical immobility. Patients' self-care needs (bathing, eating, dressing, and elimination) were not fulfilled by $90 \%$ (19 patients), and self-care needs were met by $10 \%$ ( 2 patients). The results of interviews with several nurses mentioned that self-care needs are unfulfilled because the implementation takes quite a long time. For example, to meet the needs of selfcare (bathing and attiring) requires approximately 30 minutes per patient. From the observation it was found that $10 \%$ (2 patients) of self-care needs were delivered by nurses and 90\% (19 patients) of self-care needs were met by family members and some were not delivered by the family. We conducted an initial survey and found that the daily average was 11 patients with partial dependency care, and 2 patients with total dependency care. Based on the interviews with several nurses, it was also found that nurses rarely address the self-care needs of patients, especially for personal hygiene, because they consider that it can be done by families. In addition, nurses tend to prioritise dependent and collaborative interventions rather than fulfilling the basic needs of patients. It causes the unfulfilled self-care needs of patients with physical immobilisation.

A self-care deficit problem would influence body hygiene such as skin infections, altered circulatory system, uncomfortable and less confident. From the results of the Community Satisfaction Index (CSI) data at an inpatient ward in one of a public hospital in Surabaya in 2010 were in the good category $(7.78 \%)$, but nursing care had the lowest value of 2.91 compared to medical and pharmacy services. It was found that there was an increasing number of complaints due to unfulfilled personal hygiene needs from 2010 to 2016 . The existence of this phenomenon proves that the implementation of nursing care still is not optimal, especially in self-care needs, thus greatly affecting the quality of service of health care.

Analysis of the factors affecting selfcare needs could be conducted as problem solving in patients with physical immobilisation. Patients could understand the most dominant factors and appropriate interventions to fulfil their self-care needs. Thus, the aim of this study was to analyse the factors that can affect the fulfilment of selfcare needs in patients with physical immobilisation.

\section{MATERIALS AND METHODS}

This study design was cross-sectional, where research is done by focusing on the time of measurement as well as observation of the independent and dependent variable data at one time only. Independent variables and the dependent variable were rated simultaneously and there was no follow-up (Nursalam, 2013).

The population in this study was all patients with physical immobilisation treated in Graha Nuur Afiyah Inpatient RSU Haji Surabaya on $2^{\text {nd }}, 3^{\text {rd }}$ and $4^{\text {th }}$ floors, with the total respondents numbering 36 patients and 42 nurses. Sampling was selected by purposive sampling, to obtain the patient and nurse respondents who met the inclusion criteria, totalling 36 respondents. The data were analysed using multiple linear regression test with a significance level of $p<0.05$.

This study has been conducted with ethical clearance by the Ethics Commission, Faculty of Nursing, Universitas Airlangga. The ethical principles applied in this study include the benefiency principle, the principle of respect for human diginity, justice ti right principle, and the principle of right to freedom.

\section{RESULTS}

This section will present the results of the study based on factors of patients towards self-care needs, implementation of nursing care and fulfilment of self-care needs.

Table 1 shows that most respondents were elderly with an age range between 56-65 years as many as 16 people $(44.4 \%)$ and the majority of the patients were male with as many as 19 people $(52.8 \%)$.

Based on Table 2, showed that most of the respondents had good knowledge of as 
Table 1 Distribution of factors of patients toward self-care needs in patients with physical Immobilization

\begin{tabular}{lcc}
\hline Variable & Freq & Percentage (\%) \\
& & \\
\hline Age (years) & 5 & 13,9 \\
$26-35$ & 5 & 13,9 \\
$36-45$ & 4 & 11,1 \\
$46-55$ & 16 & 44,4 \\
$56-65$ & 6 & 16,7 \\
$>65$ & 36 & 100,0 \\
\hline Total & & 52,8 \\
\hline Sex & 19 & 47,2 \\
Male & 17 & 100,00 \\
\hline Female & 36 &
\end{tabular}

Table 2 Distribution of factors of nurse toward self-care needs in patients with physical Immobilization

\begin{tabular}{lcc}
\hline Variable & Frequency & $\%$ \\
\hline Knowledge & & \\
Poor & 0 & 0 \\
Fair & 7 & 19,4 \\
Good & 29 & 80,6 \\
\hline Total & 36 & 100,00 \\
\hline Intervention & & \\
Poor & 19 & 52,8 \\
Fair & 9 & 25,0 \\
Good & 8 & 22,2 \\
\hline Total & 36 & 100,00 \\
\hline Motivation & & \\
Poor & 13 & 36,1 \\
Fair & 21 & 58,3 \\
Good & 2 & 5,6 \\
\hline Total & 36 & 100,00 \\
\hline
\end{tabular}

many as 29 people (80.6\%), acts less as many as 19 people $(52.8 \%)$, and motivation that are as many as 21 people $(58.3 \%)$ in meeting the needs of self-care (self-care) in patients with physical immobilisation.

Table 3 shows that in the implementation of nursing care methods based on role nursing unit manager, primary nurse, associate nurse, and teamwork, the average was poor.

Table 4 shows that most respondents with physical immobilisation (72.2\%) were not satisfied in terms of their self-care needs (self-care). Most patients (41.7\%) had unfulfilled self-care needs for eating, elimination was 26 patients $(72.2 \%)$, attiring in a total of 27 patients (75\%), and the elimination a total of 27 patients $(75 \%)$.

Based on the test results ANOVA pvalue (Sig.) $=0.000$, it indicates that the variable age of the patient, gender of the patient, the nurse's knowledge, the intervention of nurses and nurse motivation simultaneously affect self-care in patients with physical immobilisation. The coefficient of determination (R Square) $=0.88988 .9 \%$; this means that care needs (self-care) in patients with physical immobilisation can be explained by patient age, gender of the patient, the nurse's knowledge, the actions of nurses and nurse motivation, while the remaining $11.1 \%$ $(100 \%-88.9 \%=11.1 \%)$ can be explained by other variables that are not included in this study.

The partial test results showed that the patient's age variable with $\mathrm{p}$ value (Sig.) 0.005 . It means that $\mathrm{H} 1$ was accepted; age significantly affects patients' care needs (selfcare) in patients with physical immobilisation. Patients' gender variable $p$ value (Sig.) 0.038; thus, $\mathrm{H} 1$ is accepted, which means that the sex

Table 3 Implementation of nursing care methods

\begin{tabular}{lcc}
\hline $\begin{array}{l}\text { Implementation of } \\
\text { nursing care methods }\end{array}$ & $\begin{array}{c}\text { Freq } \\
(\%)\end{array}$ & Classification \\
\hline $\begin{array}{l}\text { Graha Nuur Afiyah } \mathbf{2}^{\text {nd }} \\
\text { floor }\end{array}$ & & \\
$\begin{array}{l}\text { Duty and responsibility of } \\
\text { Nurse Leader }\end{array}$ & 23,3 & Poor \\
$\begin{array}{l}\text { Duty and responsibility of } \\
\text { Primary Nurse }\end{array}$ & 26,1 & Poor \\
$\begin{array}{l}\text { Duty and responsibility of } \\
\text { associate nurse }\end{array}$ & 21,7 & Poor \\
$\begin{array}{l}\text { Teamwork } \\
\text { Total }\end{array}$ & 29,0 & Poor \\
\hline $\begin{array}{l}\text { Graha Nuur Afiyah } 3^{\text {rd }} \\
\text { floor }\end{array}$ & 100 & \\
$\begin{array}{l}\text { Duty and responsibility of } \\
\text { Nurse Leader }\end{array}$ & 22,2 & Poor \\
$\begin{array}{l}\text { Duty and responsibility of } \\
\text { Primary Nurse }\end{array}$ & 26,0 & Poor \\
$\begin{array}{l}\text { Duty and responsibility of } \\
\text { associate nurse }\end{array}$ & 19,3 & Poor \\
$\begin{array}{l}\text { Teamwork } \\
\text { Total }\end{array}$ & 29,6 & Poor \\
\hline $\begin{array}{l}\text { Graha Nuur Afiyah } \mathbf{4}^{\text {th }} \\
\text { floor }\end{array}$ & 100 & \\
$\begin{array}{l}\text { Duty and responsibility of } \\
\text { Nurse Leader }\end{array}$ & 23,1 & Poor \\
$\begin{array}{l}\text { Duty and responsibility of } \\
\text { Primary Nurse }\end{array}$ & 27,2 & Poor \\
$\begin{array}{l}\text { Duty and responsibility of } \\
\text { associate nurse }\end{array}$ & 21,7 & Poor \\
$\begin{array}{l}\text { Teamwork } \\
\text { Total }\end{array}$ & 28,0 & Poor \\
\hline & 100 & \\
\hline
\end{tabular}


Table 4 Fulfilment of self-care needs in patients with physical immobilization

\begin{tabular}{|c|c|c|c|}
\hline Self-care items & Freq & $(\%)$ & Classification \\
\hline Eating unfulfilled & 15 & 41,7 & Poor \\
\hline Eating fulfilled & 21 & 58,3 & Poor \\
\hline Total & 36 & 100 & \\
\hline $\begin{array}{l}\text { Bathing } \\
\text { unfulfilled }\end{array}$ & 26 & 72,2 & Poor \\
\hline Bathing fulfilled & 10 & 27,8 & Poor \\
\hline Total & 36 & 100 & \\
\hline $\begin{array}{l}\text { Attiring } \\
\text { unfulfilled }\end{array}$ & 27 & 75,0 & Poor \\
\hline Attiring fulfilled & 9 & 25,0 & Poor \\
\hline Total & 36 & 100 & \\
\hline $\begin{array}{l}\text { Elimination } \\
\text { unfulfilled }\end{array}$ & 27 & 75,0 & Poor \\
\hline $\begin{array}{l}\text { Elimination } \\
\text { fulfilled }\end{array}$ & 9 & 25,0 & Poor \\
\hline Total & 36 & 100 & \\
\hline
\end{tabular}

of the patient significantly influences the care needs (self-care) in patients with physical immobilisation. Nurses' knowledge variable $\mathrm{p}$ value (Sig.) 0.889; thus, H1 is accepted, so nurses' knowledge does not significantly affect the care needs (self-care) in patients with physical immobilisation. Nurse implementation variable $\mathrm{p}$ value (Sig.) 0.000 means that actions significantly affect the care needs (self-care) in patients with physical immobilisation. Nurses' motivation variable $p$ value (Sig.) 0.003 means that actions significantly affect the care needs (self-care) in patients with physical immobilisation. The results showed that the most dominant variable was factors of nurses, with standard regression koefisien 0.523; the nurse care implementation is able to explain the variable Y (self-care) amounting to $44.2 \%$, while the patient factors, the dominant variables (factors nurse) (number 3 ), are the age of the standard regression coefficient -0.270 , wherein the variables of age are able to explain the variable Y (selfcare) of $21.5 \%$.

\section{DISCUSSION}

\section{Correlation between patient's age and self- care needs in patients with physical immobilisation}

Based on the results of the research, most respondents aged 56-65 years reported that the patient care needs (self-care) in patients with physical immobilisation are not met. From the test results, statistical regression analysis of patients' age variable (X1) has a significant correlative relationship partially or simultaneously to variable care needs (selfcare) (Y).

Hermawati (2016) showed that most respondents were over 50 years old. Based on statistical test results, the $\mathrm{p}$ value was 0.006 , which means that there was a significant correlation between age and self-care related to self-care in patients undergoing hemodialysis.

Orem (2001, cited in Purwoastuti, 2016) found that infants, the elderly and sick people need assistance to meet their self-care needs. The age factor is related to people's experience in dealing with various stressors, the ability to use support resources and skills in coping mechanisms (Stuart \& Laraia 2005). The self-care ability of a person is affected by age, stage of development, life experiences, socio-cultural background, health, and resources (Marriner 2001). Normal growth and development according to age include changes in the biological, cognitive, and socioemotional functions that occur during the life of the individual (Santrock 2007). Growth includes physical changes that have occurred from the prenatal period to adulthood, which continue to be progress or setbacks. The development is dynamic and involves a progression and a decrease (Berger 2005). In the elderly, the aging process occurs in a linear manner and can be described in three phases:

Table 5 Factors affecting the fulfilment of self-care needs in patients with physical immobilization

\begin{tabular}{lcccccc}
\hline $\begin{array}{l}\text { Independent } \\
\text { variable }\end{array}$ & Konstanta & $\begin{array}{c}\text { Beta } \\
\text { (Coeficien } \\
\text { Regression) }\end{array}$ & $\mathrm{R}$ & $\mathrm{R}$ Square & $\begin{array}{c}\text { P-value (Sig.) } \\
\text { ANOVA } \\
\text { (Simultant) }\end{array}$ & $\begin{array}{c}\text { P-value (Sig.) } \\
\text { (Partial) }\end{array}$ \\
\hline Age & 0,702 & $-0,093$ & & & & 0,005 \\
Sex & 0,147 & 0,943 & 0,889 & 0,000 & 0,038 \\
Knowledge & & $-0,010$ & & & & 0,889 \\
Action & & 0,289 & & & & 0,000 \\
Motivation & & 0,180 & & & & 0,003 \\
\hline
\end{tabular}


impairment, functional limitations and disability, and handicap will be experienced simultaneously with the process of degeneration (Bondan 2006). Age will lead to changes in the structure and physiological bases of various cells / tissues / organs and systems in the human body. This process causes physical and psychological deterioration. Setbacks to psyche that occur in the form of an increase in emotional sensitivity, decreased arousal, increased interest in self-esteem, lack of interest in the appearance, increasing interest in the material, and interest in leisure activities has not changed (only the orientation and subjects are different), and there is a downward trend in taking care of themselves (Mubarak, 2009). This showed that the older the ability in selfcare will be decreased so that the self-care needs of the elderly (aged 56-65 years) were unfulfilled.

\section{Correlation between patient's sex and self- care needs in patients with physical immobilisation}

The survey results revealed that most respondents were male patients and the selfcare needs of patients with physical immobilisation are not met. The test results obtained that statistical regression analysis of patients' gender variable (X2) shows a partial significant correlation to the care needs (selfcare) (Y) variable in patients with physical immobilisation.

Research conducted by Mahanani (2013) also explained that calculations using correlation Chi-square test with a level of $95 \%$ obtained $\mathrm{p}$ value $0.008<0.05$, so the hypothesis is accepted, which means it can be seen that there was a relationship between gender and care specialising in leprosy patients at Blora in 2011. Sex includes the physical traits, character and different properties that affect the cleanliness of a person (Stuart \& Laraia, 2005). Problemsolving skills, analytical skills, competitive urge, motivation, sociability and ability to learn are the same between men and women (Rohman, 2007). Gender relates to the role of life and the different behaviour between men and women in society. In maintaining their health, women typically fare better than men. Differences ill behaviour are also influenced by gender, as women more often take care of themselves than men.

Hermawati's study (2016) explains that the statistical test results with $\mathrm{p}$ value 0.793 mean that there was no significant relationship between gender and self-care. In self-care, gender is one of the factors that influence self-care. Women usually tend to be more concerned with their physical appearance than men.

\section{Correlation between nurses' knowledge and self-care needs in patients with physical immobilisation}

The results of this study found that most respondents felt that nurses have good knowledge of the self-care needs of patients and care needs (self-care) of patients with physical immobilisation are unfulfilled. The regression analysis showed that nurses' knowledge (X3) had no significant correlation to the care needs variable (self-care) $(\mathrm{Y})$ in patients with physical immobilisation.

Notoatmodjo (2007) explained that knowledge is a process of knowing what happens after someone did sensing through the five senses of sight, hearing, smell, taste, and touch on a specific object. Nurses should have the knowledge to give professional nursing care. The level of knowledge of each individual is different. It is influenced by many factors, including age, level of education, resources, experience, economic, environmental, and socio-cultural (Notoatmodjo, 2007). In the field of nursing, nurses' knowledge can continue to evolve with different variations depending on experience, education and nursing initiatives in reading literature or other information sources. The depth and breadth of nurses' knowledge can also affect their ability of critical thinking and their ability to deal with problems (Potter \& Perry, 2010).

Research conducted by Darmiati (2008) in the city of Napier showed that there was a relationship between knowledge to require the needs of personal hygiene. Patients with immobilisation could not take care for themselves; patients need assistance to fulfil self-care. In this case, nurses' awareness needed to be more attentive and more active. Self-care is often considered a trivial issue, but it also affects a person's health and psyche; therefore, the nurse should always want to 
motivate patients to maintain self-care (Nurhaeni 2012).

Level achieved perfection nursing care depends on the willingness, ability, knowledge and skills are both nurses (Nursalam 2016). Based on this theory, researchers assume that even if a nurse at Graha Nuur Afiyah RSU Haji Surabaya has a level of knowledge in the range of sufficient to good, if it is not supported by a strong willingness to take care, it will affect the nurse in the implementation of caring for the needs of the patients, which can cause unfulfilment of the patient's needs, especially for a patient with physical immobility.

\section{Correlation between nurse's implement- ation of self-care needs in patients with physical immobilisation}

The survey showed that most nurses had less action in giving the needs of self-care in patients with physical immobilisation. From the statistical regression analysis the nurse action variable (X4) has a significant correlation partially or simultaneously with variable care needs (self-care) (Y) in patients with physical immobilisation. The test results show that the action variable is the dominant factor in influencing the self-care needs (selfcare) of patients with physical immobilisation.

Orem (2001, in Aligood, 2014) explains that the theory of the nursing system describes and explains how patients' self-care needs are fulfilled by nurses or patients themselves; Orem argues about the fulfilment itself, the needs of the patient, and the patient's ability to perform self-care. Measures to help meet the needs of personal hygiene and selfcare are not a skill that can only be learned in a short time; there is a need for customs, experience and good communication. Nurses always perform personal hygiene measures to be more skilled in providing services and will get excellent results (Sandyarman 2014). This is according to research by Gunadi (2001) on the fulfilment of self-care performed by nurses for immobilised patients; services to provide personal hygiene measures are maximised if the nurse has a good skill in providing nursing care. Skill can be increased with training and improved ability to get the maximum results. The result showed that the majority of nurses less action care needs (self-care); thus, patients' care needs are unfulfilled. Based on interviews with several nurses during the initial survey, the exercise of self-care (selfcare), especially personal hygiene, among others requires longer periods of time, because nurses have to finish other nursing care. In addition, nurses rarely address the self-care needs of patients, especially for personal hygiene, because they consider that it can be done by families and caregivers and they only help if needed. Nurses tend to prioritise other independent and collaborative action other than to address the basic needs of patients. It could cause the unfulfilment of self-care in patients with physical immobilisation.

Maria (2010) said that immobilised patients depend on the self-care nurse, so the nurse providing personal hygiene must have the desire to achieve satisfactory results. Patients will be satisfied if the perception is equal to or higher than expected. Excellent nursing in providing self-care will lead to the satisfaction of the patient. Damayanti (2010) showed that there was a significant difference in patient satisfaction before and after the implementation of personal hygiene in patients with immobilisation.

Based on several studies and theories that have been described and facts obtained during the study, the implementation or intervention is a dominant factor in determining self-care needs. Nurses are expected to provide self-care by both the patient and the nursing care according to the standards that have been made, in order to increase the satisfaction of patients and to prevent negative impacts on the physical immobilisation as a result of unfulfilled demand for self-care.

\section{Correlation between nurse's motivation and self-care needs in patients with physical immobilisation}

Based on the results, it can be seen that most nurses had moderate and poor motivation in fulfilling the self-care needs of patients with physical immobilisation. Statistical regression analysis showed that nurses' motivation variable (X5) has a significant correlation, partially or simultaneously, to variable care needs (selfcare) (Y) in patients with physical immobilisation.

According to Suarli (2009), motivation is one of the factors that may affect performance. Performance of the nurses to fulfil patient needs. Riyadi and Kusnanto 
(2007) stated that in improving the quality of health services, every nurse should have high motivation for obtaining a good performance. The higher the motivation of the nurse, the higher the performance of nurse will be.

Motivation is a feeling or a thought that drives someone to do something or the exercise of power, especially in the action (Sortell \& Kaluzny, 1994 in Suarli and Bahtiar, 2009). Motivation is composed of intrinsic and extrinsic motivation. One of the most visible is intrinsic motivation. Nawawi (2004) defined intrinsic motivation as a condition that encourages an activity that is within in the activity itself. Conditions shape awareness about the meaning and benefits of an action or activity, either for themselves or others and the wider community. Raatikainen (1997) in his research found that someone who gets the willingness to become a nurse has professional knowledge and motivation and understands the actions of nursing and also can be a source to provide support for the patient. Nursing services can be effective when there is motivation as the driving passion, driving someone to do something desired. It will be well maintained when there is a good communication (Mundzakir 2006).

This study demonstrates that the motivation of nurses was poor or fair. Poor motivation leads to the lower performance of nurses in terms of addressing self-care needs that should be independent nurse care. Based on the demographic data, half of the nurses have also had a long working life of 16-20 years. Maryoto (1990, in Ismael, 2009) argues that if a person has not worked long enough, it will result in the poor, among others not yet appreciate the work that they are responsible. The tenure of the person that is too long in an organisation is a symptom that is not healthy. Possible consequences include boredom of doing the same job for a long time, passivity and resignation of motivation and initiative in work, affecting one's creativity because there is no challenge. Job satisfaction is relatively high at the time of first starting but declines gradually over the next 5-6 years and increases the satisfaction to a peak after 20 years. Such long working lives will also affect the decline in motivation of nurses in terms of patients' self-care needs. In addition, based on the items on the questionnaire respondents about $\mathrm{C} 11$ nurses, it was found that the majority of respondents stated that the salary / award obtained from the hospital is not in accordance with the toil issued; in this case, when the nurse helps to meet patients' care needs. Landy and Becker, cited in Nursalam (2016), grouped into 5 categories of motivational theories, one of which is the theory of justice. The theory of justice is based on the assumption that the main factor in the motivation of the work is the evaluation of the individual or the fairness of awards received. Individuals will be motivated if they get balanced with the business they do.

Various explanations above can explain the decline in the motivation of nurses to meet the self-care needs of patients due to the average age of nurses in the room and the imbalanced awards received by nurses, thus causing the self-care needs of patients to remain unfulfilled.

\section{Correlation between nursing care and self-care needs in patients with physical immobilisation}

Based on the survey results, the conduct of the nursing care method is in fair range. Murwani (2008) stated in the Health Sciences Consortium in 1989 that the role of nursing is that of a care giver. The role as care giver of nursing care can be done when nurses pay more attention to the basic human needs through the provision of nursing care using the nursing process, so nursing diagnosis can be planned and implemented appropriately in accordance with the level of basic human needs, then evaluated for its development. Nursing care is carried out from simple to complex. In this study, nurses play an important role in nursing care, especially in the self-care needs of patients. The results showed that the nursing care is in the fair range. This is because each element of the nursing care method (Head Nurse, Primary Nurse, and Associate nurse) was not optimal in carrying out its duties and responsibilities. From the analysis of questionnaires, it is clear that the duty and responsibility of the Head Nurse was not optimal. This is indicated by the fact that the head of the room sometimes (with frequency 1-2x a week) had discussions with a $\mathrm{PN}$ or AN to provide guidance on the issue of self-care needs, and rarely undertook supervision on the fulfilment of self-care needs. In addition, the duties and responsibilities of the PN were also not 
optimal, as indicated by the PN occasionally during the study evaluating nursing care with regard to self-care needs, as well as rarely meeting with patients and families to discuss the issue of self-care. The AN observed during the study sometimes performed acts addressing self-care needs. This is in line with the results of interviews conducted by the researchers as a preliminary survey on some of the nurses; the AN only performed these activities when families of patients asked for help to meet the needs of self-care such as personal hygiene (bathing and dressing) and elimination.

Craven, in Agustin (2002), explained that the quality of health care in hospitals is determined by the circumstances of nurses both in terms of quantity and quality. Nurses in providing nursing care to patients using nursing care management is the implementation of the nursing process. The nursing process is the basis of nursing practice that applies knowledge and theory in practice. Pinedendi (2016) explained that there was a significant impact on the implementation of nursing care in the patients' self-care deficit ( $\mathrm{p}$ $=0.003$ ); personal hygiene before and after intervention was in the fair category.

It could be concluded that the implementation of the nursing care method may contribute to addressing patients' care needs. Nurses are expected to be able to apply the method to give nursing care optimally and carry out their duties and responsibilities.

\section{CONCLUSIONS}

Based on the results of research and discussio Based on the results of the research and discussion, the researchers can make several conclusions that patient factors, nursing factors and health service factors can determine the care needs (self-care) in patients with physical immobilisation. Patient factors, especially in the elderly (55-65 years), will impact on reducing self-care needs (self-care) in patients with physical immobilisation, while the female gender will be affected by increasing care needs (self-care) in patients with physical immobilisation. In nursing factors, nurses' increased knowledge does not affect increasing care needs (self-care) in patients with physical immobilisation (selfcare needs are met). Nurses with less motivation will impact on reducing self-care needs (self-care) in patients with physical immobilisation (self-care is unfulfilled). In the health service factors, the implementation of the primary nursing care team at Graha Nuur Afiyah was in the fair range, which probably has an impact on reducing self-care needs (self-care) in patients with physical immobilisation (self-care needs are not met).

Improvements to the quality of nursing services should also be supported by good nursing performance. It was suggested that the hospital should hold seminars, workshops and training, especially with regard to fulfilling the self-care needs of patients. Subsequent researchers could expand on the sampling technique by cluster and stratified sampling, and may make observations on meeting the needs of self-care with greater observational frequency.

\section{REFERENCES}

Alligood, MR. 2013. Nursing theory: utilization \& application, Fifth edition. St Louis, Missouri: Elsevier Mosby.

Alligood, MR. 2014. Nursing Theorists and Their Work, Eight Edition. St Louis, Missouri: Elsevier Mosby

Alimul, A. 2009. Pengantar Kebutuhan Dasar Manusia: Aplikasi Konsep dan Proses Keperawatan, Buku 1. Jakarta: Salemba Medika

Anonemous. 2012. Nursing Theoris A Companion To Nursing Theori AndModels

http://currentnursing.com/nursing_th eory/self_care_deficit_theory.html

Asmadi. 2008. Konsep Dasar Keperawatan. Jakarta: EGC

Basudewo, Y., 2012. Hubungan Motivasi Intrinsik Menjadi Perawat dengan Caring Perawat di RS Mardi Waluyo Metro Lampung Tengah (Doctoral dissertation, Program Studi Psikologi FPSI-UKSW)

Berger, K. (2005). The Developing Person: Throught The Life Span. New York: Worth.

Damayanti, M.D. 2010. Efektifitas Tindakan Personal Hygiene Terhadap Tingkat Kepuasan Pasien Imobilisasi di RS. Mardi Rahayu Kudus (Doctoral disertation, Universitas Diponegoro)

Darmiati. 2008. Faktor-Faktor yang 
Berhubungan dengan Pemenuhan Kebutuhan Personal Hygiene Pasien Rawat Inap Makasar.

Depkes RI (2009). Profil Kesehatan Indonesia. Jakarta: Depertemen Republik Indonesia

Gallegos, EC. 1997. The Effect of Social, family, and Individual factors on Self-care Agency and Self-care of Adult Mexican Women. Desertasi, Wayne State University.

Graven and Himle. 2000. Fundamental of Nursing, Human Health and Function, third edition. Philladelpia: J.B. Lippincolt

Gunadi. 2002. Pemenuhan Perawatan Diri yang Dilakukan oleh Perawat pada Pasien yang Immobilisasi. Tesis. Laporan Penelitian, Universitas Indonesia

Haryono, I. 2011. Hubungan Antara Beban Kerja Perawat Dengan Pemenuhan Kebutuhan Personal Hygiene ( Kebersihan Diri ) Pasien Di Ruang Pavilyun Lantai 3 Rumah Sakit Umum Haji Surabaya. Skripsi. Universitas Muhammadiyah Surabaya

Hermawati., Hidayati, Titiek., Chayati, Nur. 2016. Faktor-Faktor Yang Mempengaruhi Self-care Diet Nutrisi Pasien Hemodialisa Di Rsud Dr. Moewardi Surakarta. STIKES 'Aisyiyah Surakarta. Gaster Vol. XIV No. 2 Agustus 2016

Hidayat, A.A. 2009. Metode Penelitian Keperawatan dan Teknik Analisis Data. Edisi Pertama. Jakarta: Salemba Medika

Ismael. 2009. Hubungan Karakteristik Perawat Terhadap Penatalaksanaan Klien Prilaku Bunuh Diri di RSJ.Prof. Dr. Hb. Sa'anin Padang Tahun 2009. Sumatera Barat : Program Studi DIII Keperawatan Stikes Perintis Bukittinggi

Johnson, B. 2015. An Introduction to Theory and Reasoning in Nursing. Wolters Kluwer Lippincott Williams Wilkins

Khasanah, S., Susanti, I.H., Safitri, M., Wita, W. and Tiva, T. 2014. Hubungan Tindakan Mandiri Personal Hygiene Oleh Perawat Dengan Tingkat Kepuasan Pasien Imobilisasi Di Ruang Rawat Inap Rsud Dr. R
Goetheng Taroenadibrata

Purbalingga. Viva Medika,7(13).

Mangkunegara, P.A.A. 2009. Manajemen sumber daya manusia. Cetakan kesembilan. Bandung : Remaja Rodakarya

Marlina, A. 2011. Faktor - Faktor Yang Berhubungan Dengan Pemenuhan Kebutuhan Personal Hygiene Pasien Rawat Inap Di Ruang Interna Rumah Sakit Umum Sawerigading Kota Palopo Periode April - Mei 2011. Skripsi

Marriner, A. (2001). Nursing Theorist and Their Work. (Alih Bahasa: Ekawijaya, I. \& Riyono, R.). India: MosbyCompany.

Muhlisin, A. \& Irdawati, 2010. Teori self-care dari Orem dan pendekatan dalam praktek keperawatn. Berita Ilmu Keperawatan, 2(2), pp.97-100

Natalia, MN. 2014. Pemberian Tindakan Personal Hygiene Terhadap Kepuasan Pasien Immobilisasi Pada Asuhan Keperawatan Ny S dengan Efusi Pleura Di Ruang Aster 5 RSUD Dr Moewardi Surakarta

Notoatmodjo, S. 2012. Metodologi Penelitian Kesehatan. Jakarta: Rineka Cipta

Notoatmodjo, S. 2014. Ilmu Perilaku Kesehatan. Jakarta: Rineka Cipta

Nurhaeni, H., Suryati, T. R. L., Taufiqurrachman, K. P., Manurung, S., \& Chairani, R. 2012. Pengaruh Intervensi Personal Higiene Terhadap Kepuasan Pasien Immobilisasi. Caring, 1(03), 190196

Nursalam. 2014. Metodologi Penelitian Ilmu Keperawatan Pendekatan Praktis, Edisi 3. Jakarta: Salemba Medika

Nursalam. 2016. Manajemen Keperawatan Aplikasi dalam Praktik Keperawatan Profesional Edisi 5. Jakarta: Salemba Medika

Orem, D.E. 2001. Nursing Concept of Practiced. St. Louis: the CV Mosby Company

Orem, A. T., \& Wisma, T. 2007. Aplikasi Teori Self-Care Deficit Orem dalam Konteks Tuna Wisma (Studi Literatur) (The Application of Orem ' s Self-care Deficit in Homeless Setting) Megah Andriany *, 1

Pancaningrum, D. 2011. Faktor-Faktor Yang 
Mempengaruhi Kinerja Perawat Pelaksana Di Ruang Rawat Inap Dalam Pencegahan Infeksi Nosokomial Di Rs Haji Jakarta Tahun 2011. Tesis. Universitas Indonesia

Pinedendi, Novita., Rottie, Julia Villy., Wowiling, Ferdinand. 2016. Pengaruh Penerapan Asuhan Keperawatan Defisit Perawatan Diri Terhadap Kemandirian Personal Hygiene Pada Pasien Di Rsj. Prof. V. L. Ratumbuysang Manado. e Journal Keperawatan $(e-K p)$ Vol 4 No 2, Juli 2016

Potter \& Perry. 2013. Fundamentals of Nursing Eighth Edition. Missouri: Elsevier Mosby

Riyadi, Sujono, Harmoko. 2012. Standard Operating Procedure dalam Praktik Klinik Keperawatan Dasar. Yogyakarta: Pustaka Pelajar

Santrock, J. 2007. Life Span Development.9th $E d$.New York: McGraw-Hill.

Setiadi. 2007. Konsep dan Penulisan Riset Keperawatan. Yogyakarta: Graha Ilmu

Setiati, S. 2015. Penatalaksanaan Imobilisasi dan Komplikasi Akibat Imobilisasi pada Orang Usia Lanjut. Divisi Geriatri Departemen Ilmu Penyakit Dalam FKUI RSCM

Slevin, O \& Basford, L. 2006. Teori dan Praktik Keperawatan Pendekatan Integral pada Asuhan Pasien. Jakarta: EGC

Stuart, G. W. \& Laraia, M. T. 2005. Principle and Practice of Psychiatric Nursing. 6th Ed. Philadelphia: MosbyInc.
Suarli, S \& Bahtiar, Y. 2009. Manajemen Keperawatan dengan Pendekatan Praktis. Jakarta: Penerbit Erlangga

Sulistyowati, D. \& Handayani, F. 2012. Peran Perawat Dalam Pelaksanaan Personal Hygiene Menurut Persepsi Pasien Imobilisasi Fisik. Jurnal Nursing Studies, 1, pp.169-174.

Susanti, H. 2010. Defisit Perawatan Diri Pada Klien Skizofrenia: Aplikasi Teori Keperawatan Orem. Jurnal Keperawatan Indonesia. Http://Jki.Ui.Ac.Id/Index.Php/Jki/Art icle/Viewfile/237/Pdf_166

Sandyarman, I Nyoman Gede. 2014. Hubungan Personal Hygiene Oleh Perawat Dengan Tingkat Kepuasan Pasien Imobilisasi Di Rumah Sakit Jember Klinik. Artikel Jurnal. Universitas Muhammadiyah Jember

Taylor, S., \& Renpenning, K. 2011. Self-care Science, Nursing Theory and Evidence Based Practice. New York: Springer Publishing Company, LLC

Tommey, A.M., dan Alligood, M.R. 2006. Nursing Theory And Their Work. Missouri: Mosby

Uno, H. 2011. Teori Motivasi dan Pengukuranya: Analisis di Bidang Pendidikan. Jakarta: Bumi Aksara

Wasis. (2008). Pedoman Riset Praktis untuk Profesi Perawat. Jakarta : EGC.

Wahyudi, AS \& Wahid, A. 2016. Buku Ajar Ilmu Keperawatan Dasar. Jakarta: Mitra Wacana Media

widuri, H. 2010. Kebutuhan Dasar Manusia: Aspek Mobilitas da Istirahat Tidur. Yogyakarta: Gosyen Publishin 